\title{
Role of Financial Inclusion to Stability: The Case of Indonesia's Sharia Banking
}

\author{
Estu, WIDARWATI, \\ STIE Sutaatmadja, Otista 76 Subang, \\ e_witd@yahoo.com \\ PindyKurnia, SARI, \\ STIE Sutaatmadja, Otista 76 Subang, \\ pindykurnia_9g@yahoo.co.id \\ Nunik, NURMALASARI, \\ STIE Sutaatmadja, Otista 76 Subang, \\ nuniknurmalasari90@gmail.com
}

\begin{abstract}
Public access to the services of financial institutions determines the revenues amount of financial institutions. The growth of bank account helps banks to manage the financing service that provides for the community. This study examines the relationship of financial inclusion and financial stability, especially in Indonesia's Sharia banking. Financial inclusion defined as community access to financial services which peroxided by deposits, while the financial stability of Sharia banking is measured by Non Performing Financial (NPF). Samples include financial data of 5 sharia banks during the study period from 2011 to 2016 were analyzed using classical assumption test and regression test. The results of study found that the deposits as proxy of financial inclusion had a positive effect to stability of financial.
\end{abstract}

Keywords: Financial inclusion, Financial Stability, Sharia Banking

JEL Classification: G20.

1. Introduction

The dynamics of financial inclusion became a very important economic issue after the 2008 crisis as it relates to the stability of financial system in which, when the macroeconomic environment in this case community income is unstable and will contribute to financial turmoil. On the other hand, the lowincome growth of the community is determined by the optimal or least knowledge of the community about financial institutions and their access to financial services Therefore, a balance between financial inclusion and financial system stability is essential. 
In case of Indonesia, bank's financing as one of the financial services is a form of financial inclusion efforted by Indonesia Central Bank for improving the efficiency of financial system. It is done in order for strengthening security of Indonesia's financial industry to address potential risks that may affect the stability of financial system.

Financial inclusion is needed to extend the reach of banking network to the entire community to improve financial system efficiency through the development of Micro, Small and Medium Enterprises (MSMEs) so that the results will be able to reduce intermediary costs and improve the community welfare

Likewise, the account of deposits as third party funds that became one of the sources for operational activities of Sharia banks as business financing. When it compiled by Sharia Bank increases, they have a great opportunity to increase the amount of financing that distributed to the public. Furthermore, a greater access to bank deposits can optimize deposit funding in banking then support financial stability of it's and the entire financial system (Han \&Melecky, 2013).

The low inclusion of financial cause many people have not access of financial. This phenomenon is not only happening in Indonesia but also around the world. When compared to the value of Indonesia's Financial Inclusion Index that Indonesia has the lowest index of financial inclusion among the seven countries in Asia due to the access and use of relatively low financial services, high barriers, and people who have low income.

Several previous studies have shown the role of financial inclusion to financial stability (Kunt, et.al, 2014). Financial inclusion have positive contribution to stability of bank assets in diversification form to reduce risk, increase stability deposit base, reducing liquidity risk; and increase monetary policy transmission. Conversely, inclusion may play a negative role by raising the erosion of credit standards such subprime (Khan 2011)

This study analyzes financial inclusion of sharia banks in Indonesia and its impact to banking financial stability within the period of 2012 - 2016. The proxies of financial inclusion are bank deposits (Han \&Melecky, 2013). It is based on the argument that Sharia banking becomes one option to accommodate the financing of MSMEs. As for the financial stability of Sharia banking is measured by NPF that following the research of Hannig and Jasen (2010).

\section{Literature Review}

\subsection{Financial Inclusion}

Several previous studies have shown the role of financial inclusion to financial stability (Kunt, et.al, 2014). Inclusion of financial can reduce risk, 
increase stability deposit base, reducing liquidity risk; and increase monetary policy transmission. Conversely, inclusion may play a negative role by raising the erosion of credit standards such subprime (Khan 2011)

This study analyzes financial inclusion of sharia banks in Indonesia and its impact to banking financial stability within the period of $2012-2016$. The proxies of financial inclusion are bank deposits (Han \&Melecky, 2013). It is based on the argument that Sharia banking becomes one option to accommodate the financing of MSMEs. As for the financial stability of Sharia banking is measured by NPF that following the research of Hannig and Jasen (2010). Khan (2011) states that inclusion of financial includes a process of certainty access to timely and adequate financial and credit that needed by vulnerable groups such as weak and low income group at affordable costs. This is primarily an access to bank accounts supported by deposits, access to affordable credit and payment systems. Financial inclusion aims to attract populations "who do not have access to finance" into the systems of financial then they have financial access opportunity such deposit, transfer, credit, and others of financial services (Hannig\&Jasen, 2010).

Financial Inclusion positively affects tor the lowest level of society that they can have savings recorded in financial institutions, access financing from financial institutions, and increase the ability of soft skill and hard skill. In economic development of Indonesia, banks play a big role to be the driving force financial inclusion activities. From a macro perspective, this activity is expected to support more inclusive and sustainable economic growth, and can benefit the people welfare. Furthermore, financial inclusion is expected to support the financial stability as foundation of solid economic development.

In the Indonesian context, as statement of Indonesia's Central Bank (2017), there are several measurements of financial inclusion. The terms of access are measured by the ability to use formal financial services such as the number of offices and ATMs. Other side, in terms of usage measured by actual using of financial products and services such as the number of deposits and the amount of credit/financing, as well as quality aspects that measure the availability of attributes of financial products and services have met customer needs such as affordability, transparency, convenience, fair treatment, consumer protection, financial education, indebteness and other options (choice).

This study emphasizes financial inclusion in Sharia banks, which its financing services are for MSMEs so that the proxy for financial inclusion is measured by number of deposits that following the previous research (Han \&Melecky, 2013).

\subsection{Financial System Stability}

Financial System Stability is a condition of a strong financial system and resistant to economic disturbances so that it remains able to perform the function of financial intermediation in order to function properly and support economic growth. According Singala and Asher (2008) financial stability refers to 
the smoot functioning of financial market and institutions without serious disruptions. Financial stability scope include economy's mechanism for pricing, allocation, and managing the financial risk such credit, liquidity, and others. All are functioning well that can support economy's performance.

Financial system instability can be triggered by turnmoilsmarke failure that can be sourced from external (international) and internal (domestic). Those risks effect the activities of financial system such credit, liquidity, market and operational.

Technological development supports globalization trend of financial sector. The financial system is more integrated without time lag and borders, then financial innovations are increasingly dynamic and diverse of risks. These changes are sources increasing financial system instability and it leads to more difficult to overcome the stability.

This 1998 crisis proves that financial system stability is a very important aspect in shaping and maintaining a sustainable economy. Unstable financial systems tend to be vulnerable to shocks, thereby disrupting the rotations of the economy. Financial system stability is important in economic system because it will form a good market, control and allocation of various existing resources can be optimally conditioned. The stability of the financial system has a direct impact on the banking world where a stable financial system will enable banks to perform their functions as collectors and distributors of public funds maximally which will also affect the real sector. Instability of the financial system has a considerable influence on the occurrence of monetary crisis, so it takes a maximum effort in maintaining financial system stability.

Financial system stability can be measured by capital adequacy, asset quality, financial system management, revenues and profits, liquidity, sensitivity to market risk, economic growth, and so on. In macro terms, it can be seen through aggregate growth rates, country deficits, and the adequacy of foreign exchange reserves, the amount of foreign loans, inflation volatility, interest rates, and exchange rates. While in micro-prudential (aggregate), Financial system stability is reflected from the performance of banking such aggregate capital ratio, NPL, DER, LDR, ROA, ROE, exchange rate risk, and so on.

This study focuses on the financial stability of Sharia banking and use Non-Performing Financing (NPF) as proxy of financial stability following Hannig and Jasen (2010). It based on the argument that high NPF will have potential financial risk for bank operational and then can impact to economy stability as liquidity risk.

\subsection{The Role of Financial Inclusion toward Financial Stability}

Sharia banking has great potential in implementing financial inclusion to maintain financial system stability (Kunt et al, 2013). The role of Sharia banking is very important for the economy today. In general, the function of Sharia banking is as same as conventional banking, which is as intermediary institution of financial sector with the real sector. However, it is very striking difference between Sharia banking and conventional banking in its operations as main objective. Conventional banking has shifted its purpose of aiming at profit 
oriented. While Sharia banking still aims to bridge the movement of financial sector in real sector.

Rashid et.al (2017) state that financial services offered by Islamic institutions such Sharia banks are expected to strength of financial stability. This is supported by other some literatures such Bourkhis and Nabi (2013) and alsoAhmed (2010) that Sharia banks have been least impacted by financial crisis, and having role in stabilizing the economies. The role of Islamic or Sharia banking in promoting financial system stability is an important issue. There are some evidence that Islamic or Sharia banks contribute positively to the financial stability of banking sector and in turn, to the economy (Rashid et al, 2017; Borkhis\&Nabi, 2013). However, the said impact has not been well researched in case of Sharia banking in Indonesia.

Indonesia is a country with medium category inclusion (Sanjaya, 2015) and requires increased inclusiveness through accessibility and availability. The availability of financial services and the ease of accessing financial services is an important aspect to enhance the role of the financial sector. If access to financial services does not run smoothly will be a financial risk. Financial risk, in this case, is related to financial inclusion reflected by the amount of deposit and outstanding loan. Financial inclusion also determines the bank's ability to provide financing services and optimize its management. If the Financial Inclusion does not run smoothly, it will result in impaired financial system stability. Below the framework of this research is as follows:

Figure 1. Framework of research

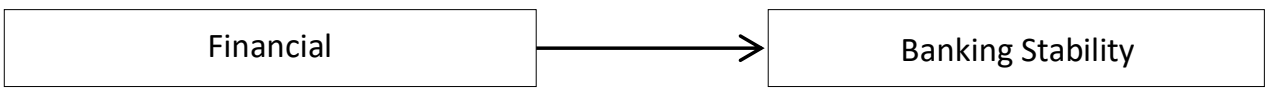

Source : Author, 2017

Deposits and the financing portions disbursed by financial institutions are illustrations of financial inclusion. This is done so that all levels of society, especially the middle to lower community can access banking easily. In general, middle to low-income people usually work in the informal sector such as MSMEs, so that when the distribution of financing in the sector increased it can be used as a picture of increased financial inclusion. Ease of banking access such as MSMEs sector financing able to develop their business and can generate income to repay the loan. The smooth and non-problematic amount of financing (NPF) that is under control makes the stability of sharia banking stable. 
Non Performing Financing remains a frightening specter for banks, the high NPF, especially bad credit, contributed greatly to the poor performance of banks at the time. NPF is one indicator of whether good or bad the Bank.

This study is in line with research conducted by Hannig and Jasen (2010) also state that financial inclusion (MSMEs) can affect the stability of banking. Therefore, this study forms the following hypothesis:

$\mathrm{H1}$ : There is a positive influence of financial inclusion on the stability of Sharia banking in Indonesia.

\section{Methodology}

\subsection{Population, Sample, and Data}

The population of this research is Indonesian Sharia Banks that 12 Indonesian Sharia Banks. The samples determined by purposive sampling that sharia bank with the completeness of data needed during the period of study 2011-2016. The samples of bank having contained MSMEs bank financing are Bank Muamalat, Bank Victoria Sharia, Sharia Mandiri, BCA Sharia and BTPN Sharia.

\subsection{Definition and Measurement of Variables}

The dependent variables of this research is financial stability and independent variable in the form of financial inclusion. In detail, the following table operations:

Table 1: Measurement of Variables

\begin{tabular}{|l|l|}
\hline Dependent Variable & Measurement \\
\hline Stability of Sharia Banking & Non Performing Financing (NPF) \\
\hline Independent Variable & \\
\hline Deposits & Total Deposits \\
\hline
\end{tabular}

Source : Author, 2018

\subsection{Data analysis method}

The method of analysis used is descriptive and quantitative and data analyzed using regression test with eviews.

\section{Results}

Descriptively, it is known that the largest portion of MSMEs financing is in Bank Mandiri Sharia and NPF highest during the 2011-2016 study period is in Bank Victoria Sharia. The following is a general overview of financing data and NPF of sharia banking Indonesia 2011-2016: 
Table 2 : Descriptive Statistics

\begin{tabular}{|c|c|c|c|c|c|}
\hline & $\mathrm{N}$ & Minimum & Maximum & Mean & $\begin{array}{l}\text { Std. } \\
\text { Deviation }\end{array}$ \\
\hline Deposits & 30 & .00084 & .56131 & .18598 & .21855 \\
\hline NPF & 30 & .0010 & .0980 & .03149 & .02687 \\
\hline
\end{tabular}

Source: Author, 2018

After the regression test with 5\% significance using eviews, it showed that the financing of MSMEs as a proxy for financial inclusion has no effect on the financial stability of Sharia banking, but contrastly deposits has positive effect. This result support the finding of Rashid et al (2017) that Sharia banks income does not solely depend on lending and rely on different source of income that positively contribute to improving the financial stability of those Sharia banks.

Table 3 : Partial Significant Test (t- Test)

\begin{tabular}{lllll}
\hline & Coeffisient & Std. Error & t-Statistic & Prob. \\
\hline C & .00201 & .00644 & 3.1264 & .0042 \\
Deposits & .0 .0569 & .01401 & 4.0608 & $.0004 *$
\end{tabular}

* denote significance at $5 \%$ levels, respectively (two-tailed test).

Hypothesis testing that has been done shows financial inclusion proxies by deposits have positive effect on Sharia banking stability of while proxy financing of MSMEs has no effect. This indicates that the high or low of financial inclusion from Sharia banks to the MSMEs sector, does not determine whether or not smooth financing is given. Increasing of financial inclusion may not determine an increase of credit standards because financial institution reduce the loan requirements for reaching low income societies.

This finding is in line with Khan's (2011) study that financial inclusion may also have a positive impact as well as a negative impact on financial system stability. Positive impacts can be attributed to financial inclusion may increase the diversification of banking assets, the stability of savings bases, and increase monetary policy transmission. Negative impacts resulted from financial inclusion may decrease credit standards because financial institutions are trying to reach unbankable lower societies by lowering loan terms, and can increase reputational bank risk. In order to improve the financial services facilities of some countries that lower the standard of establishment of a financial institution 
for rural areas, and may cause instability due to inadequate and inadequate regulation of Microfinance institutions.

The result of determination coefficient in this research is 0.3925 which becomes a record for the government to optimize the other factors of financial stability such GDP per capita rate, private banking credit, current asset value, non-capital FDI Flow ratio and the level of financial disclosure.

\section{Discussion, and Conclusions}

This research finding have important implication. First, policy makers such government and banker should decide whether to focus on reforms promoting financial development such financial inclusion through increasing deposits account as source banking funding or whether to focus on further improvement in financial stability by controlling micro prudential such non performing loan/financing as shown in this paper. We recommend that policy makers focus first on taking advantage of the synergies in financial sector. It based on argument that amount of bank deposits can benefit others and support financial system stability.

The limitations of this study which use only the dimension of use or availability as proxy for financial inclusion that should encourage further research to include other dimensions namely the accessibility and quality. Similarly, with the limited use of a single proxy as an indicator of financial stability, the NPF in this study, then we suggest for the next researcher should combine several other measures of financial stability to get better illustration of financial inclusion impact on financial stability of banks.

\section{References}

[1] Ahmed, A. (2010). Global Financial Crisis? an Islamic Finance Perspective. International Journal of Islamic and Middle Eastern Finance and Management, pp.306-320.

[2] Bourkhis,, K. \&Nabi, M.S. (2013). Islamic and Conventional Bank Soundness during the 20072008 Financial Crisis. Review of Financial Economic, pp. 68-77

[3] Hannig, A. \& Jansen, S. (2010). Financial Inclusion and Financial Stability: Current Policy Issues. Asian Development Bank Institute Working Paper Series. No 259

[4] Kunt, D., Klapper,, L., \& Randall, D. (2014). Islamic Finance and Financial Inclusion Measuring Use of and Demand for Formal Financial Services among Muslim Adults. Rev Middle East Econ Fin, pp 177-218

[5] Han, R., \&Melecky, M. (2013). Financial Inclusion for Stability : Access to Bank Deposits and The Deposits Growth during the Global Financial Crisis. MPRA Paper. No. 48339.

[6] Khan. (2011). Financial Inclusion and Financial Stability are they two sides of the same coin. Bankers Association and Indian Overseas Bank. 
[7] Mohieldin, M., Iqbal, Z, Rostom, A., Fu, Xiaochen. (2011). The Role of Islamic Finance in Enhancing Financial Inclusion in Organization of Islamic Coorperation (OIC) Countries. Islamic Economics and Finance Working Group.

[8] Rashid, A., Yousaf, S., \%Khaleequzzaman, M. (2017). Does Islamic Banking Really Strengthen Financial Stability? Empirical Evidence From Pakistan. International Journal of Islamic and Middle Eastern Finance and Management, pp. 130-148.

[9] Sanjaya, M.I., \&Nurshechafia,, N. (2015). Financial Inclusion and Inclusive Growth : A Cross Province Analysis in Indonesia. www.reserachgate.net/publication/312648291

[10] Singala, S., \& Asher, M.G. (2008). Financial Stability in Asian Economies. Economic and Political Weekly, pp. 5-71. 